\title{
DiGITALCOMMONS
}

5-1-2006

\section{Statistical Pronouncements V}

JMASM Editors

Follow this and additional works at: http://digitalcommons.wayne.edu/jmasm

Part of the Applied Statistics Commons, Social and Behavioral Sciences Commons, and the Statistical Theory Commons

\section{Recommended Citation}

Editors, JMASM (2006) "Statistical Pronouncements V," Journal of Modern Applied Statistical Methods: Vol. 5 : Iss. 1 , Article 25. DOI: $10.22237 /$ jmasm/1146457440

Available at: http://digitalcommons.wayne.edu/jmasm/vol5/iss1/25 


\section{Statistical Pronouncements V}

"I commenced a deliberate system of time-killing, which united some profit with a cheering-up of the heavy hours. As soon as I came on deck and took my place and regular walk, I began with repeating over to myself a string of matters which I had in my memory, in regular order. First, the multiplication table" Richard Henry Dana (1841, Two years before the mast: A personal narrative of life at sea).

"I had been to school most all the time and could spell and read and write just a little, and could say the multiplication table up to six times seven is thirty-five, and I don't reckon I could ever get any further than that if I was to live forever. I don't take no stock in mathematics, anyway" - Mark Twain (Samuel L. Clemens) (1884, The adventures of Huckleberry Finn).

"He said he was repeating the multiplication table over and over to steady his nerves and for pity's sake not to interrupt him, because if he stopped for a moment he got frightened and forgot everything he ever knew, but the multiplication table kept all his facts firmly in their proper place!" - Lucy Maud Montgomery (1908, Anne of Green Gables).

"It is a capital mistake to theorize before one has data" - Arthur Conan Doyle (1891, "A scandal in Bohemia: The adventures of Sherlock Holmes").

"Other things are not always equal" Edward L. Thorndike (1922, The psychology of arithmetic, NY: MacMillian, p. 12).

"There is never a quantity which does not measure some quality, and never an existing quality that in non-quantitative. Even our halos vary in diameter" - William A. McCall (1922, How to measure in education, NY: Macmillian, p. 4).

"At least a half a dozen scales now exist by which it would have been possible to measure the quality of the Handwriting on the Wall" - William A. McCall (ibid).

"Poincaré confesses that he is a rather poor numerical calculator, and so am I" Jacques Salomon Hadamard (1945, "An essay on the psychology of invention in the mathematical field", Princeton: Princeton University Press, p. 58).

"It is of utmost importance... that the third kind of error in statistical consulting be emphasized...the error committed by giving the right answer to the wrong problem" - A. W. Kimball (1957, Journal of the American Statistical Association, 52, p. 134).

"An incident from Pearson's infancy which Julia Bell once related to me... She had asked him what was the first thing he could remember... 'Well,' he said,... 'I was sitting in a high chair and I was sucking my thumb. Someone told me to stop sucking it and said that unless I did so the thumb would wither away. I put my two thumbs together and looked at them for a long time. 'They look alike to me' I said to myself, 'I can't see that the thumb I suck is any smaller than the other. I wonder if she could be lying to me' " - Helen M. Walker (1958, The contributions of Karl Pearson, Journal of the American Statistical Association, 53, p. 13)

"Pearson was a prodigious and compulsive worker. I remember asking him once how he had time to write so much and compute so much... he replied... 'I never answer a telephone or attend a committee meeting" " Samuel A. Stouffer (1958, Karl Pearson - An appreciation on the $100^{\text {th }}$ anniversary of his birth, ibid, p. 23)

"We have become accustomed to-day to a standard of published mathematical proof which can hide rather than reveal the actual process by which discoveries are made" - B. L. Welch (1958, ibid, p. 786) 
"Scientists are rarely given ladies and cups of tea to experiment with" - N. T. Gridgeman (1959, Book Review, Journal of the American Statistical Association, 54, p. 778).

\begin{abstract}
"There is often great temptation to assume... two independent runs... will inevitably be in 'reasonable agreement,' and hence that there is no need of repeating the measurement process. This is one of the most hazardous assumptions which can be made in any field of science" - Samuel Stanley Wilks (1961, Some aspects of quantification, Quantification, (Harry Woolf, Ed.), Indianapolis: Bobbs-Merrill, p. 6-7).
\end{abstract}

"It is a genius that leaps ahead of the facts, leaving the rather different talent of the experimentalist and the instrumentalist to catch up" - Thomas S. Kuhn (1961, Measurement in modern physical science, ibid, p. 42).

"The American Statistical Association is, I am told, the second oldest learned society [in America], the American Philosophical Society being the oldest. This news usually shocks our colleagues in economics, whose American Economic Association was founded forty-six years later; in science, whose American Association for the Advancement of Science came along nine years later; in modern languages, forty-four years later; in physics, sixty years later; in chemistry, thirty-seven years later, and so forth. Statistics is somehow still regarded by some as a new and youthful subject, one which is by now perhaps beyond hope of ever maturing" - W. Allen Wallis (1966, Economic statistics and economic policy, Journal of the American Statistical Association, 61, p. 2)

"Neither statisticians nor philosophers build bombs, automate production, cure cancer, meet payrolls, or carry precincts" - W. Allen Wallis (ibid, p. 2-3)

"The complaint that statistics is never the star of the show is not unlike the complaint that a lineman on a football team rarely scores any points. One who is not temperamentally suited to being a lineman ought not to take up statistics." - W. Allen Wallis (1966, ibid, p. 3)

"The Wilcoxon rank-sum test...show[s] only slight losses in both large and small sample efficiency relative to the t-test in the normal case, while in many non-normal cases, efficiency exceeds 100\%" - Duane Meeter (1967, Book Review, Journal of the American Statistical Association, 62, p. 1505)

"If your experiment needs statistics, you ought to have done a better experiment" - Ernest Rutherford (1871-1937, cited in N. T. J. Bailey, 1967, The mathematical approach to biology and medicine, NY: Wiley).

"I fear that the first act of most social scientists upon seeing a contingency table is to compute a chi-square for it" - Frederick Mosteller (1968, Association and estimation in contingency tables, Journal of the American Statistical Association, 63, p. 1).

"Any sensible analysis would reject this theory - even a Bayesian t-test using an informationless prior" - Irwin D. J. Bross (1969, Applications of probability: Science vs. pseudoscience, Journal of the American Statistical Association, 64, p. 52)

"The acid test of a good scientist is how he behaves when a favorite theory is refuted by incontrovertible facts" - Irwin D. J. Bross (ibid, p. 52).

"All of us are unable to see any virtue in criticisms of our work but in this dimension of personality Fisher undoubtedly excelled" Oscar Kempthorne (1970, Book Review, Journal of the American Statistical Association, 65 , p. 456.)

"During my 18 years," Mantle said, "I came to bat almost 10,000 times. I struck out about 1,700 times and walked maybe 1,800 times. You figure a ballplayer will average about 500 at bats a season. That means I played seven years without ever hitting a ball" - Mickey Mantle (1970, San Francisco Chronicle). 